\title{
Art-Science: From Public Understanding to Public Experiment
}

\author{
Georgina Born and Andrew Barry
}

March 2009

In their influential book Rethinking Science (2001), Helga Nowotny and her colleagues highlight the importance of 'contextualisation' to the production of knowledge in what they term 'mode-2 society'. Contextualisation involves a greater level of interaction than before between the production of knowledge, the context of its application, and relations with people, citizens or publics: 'the conventional rhetoric used to establish boundaries still distinguishes between "making" knowledge, the domain of science, and "using" (or "abusing") knowledge, which is accepted as socially constituted. This distinction emphasises the neutrality (and so authority) of science - wrongly, in our view, because it also excludes people and denies that contextualisation takes place' (Nowotny et al 2001, pp. 256-7). Contextualisation is understood here as a process in which the 'context' of knowledge production is something that has to be made, not just through the work of scientists themselves, but through the activities of a series of other institutions and professionals, as well as citizens and publics. Crucially, for Nowotny et al, contextualisation multiplies the connectedness of the institutions of scientific knowledge production to other institutions and publics, and to forms of activity that are not considered scientific and technical, including those that 'take subjective experience seriously' (ibid. p. 257).

In this paper we examine the recent burgeoning of initiatives associated with the interdisciplinary field of 'art-science'. It is tempting to view art-science as a good example of the kinds of practices associated with Nowotny et al's mode- 2 knowledge production. Support for art-science can be grasped as part of a broad array of activities that are intended to foster growing interaction between the production of scientific knowledge and non-expert citizens, while at the same promising to establish connections between scientific knowledge and those forms of 'human' and 'subjective experience' that are generally held to lie outside the domain of scientific investigation. As we will show, the institutions involved in supporting art-science often claim - in the terms of Nowotny et al's analysis - that art-science renders scientific and technical knowledge more accessible and comprehensible, as well as more accountable to its publics. They contend, then, that it contributes to the contextualisation of science in the senses suggested above.

But while this is a tempting interpretation, in what follows we want to question the idea that art-science should necessarily or solely be equated with the contextualisation of scientific knowledge. Instead we will suggest that art-science can be understood as a multiplicity, and that part of its interest lies in not being reducible to these imperatives. Indeed art-science poses definitional and conceptual challenges since, while it exists as a practical, intentional category for artists and scientists, cultural institutions and funding bodies, it forms part of a larger, heterogeneous space of overlapping interdisciplinary practices at the intersection of the arts, sciences and technologies - including such self-defined categories as new media art and digital art, interactive art and immersive art, bio-art and ecological art (Wilson 2002); while these domains abut adjacent interdisciplinary scientific and technological fields from robotics, informatics, artificial and embodied intelligence to tissue engineering and systems biology. There is thus a great deal of activity but little codification; 'art-science' amounts to a pool of myriad shifting practices and categories that are themselves relational and in formation. 
The notion of contextualisation, then, fails to capture the ways in which the emergent field of art-science exhibits its own complex trajectories, which cannot be grasped primarily as a consequence of a unitary, epochal transition in the mode of knowledge production. Drawing on ethnographic research on art-science institutions, practitioners and administrators in the UK, USA and Australia, ${ }^{1}$ in what follows we develop this argument in two ways. Our first aim is to indicate the heterogeneity of art-science and of the experiments carried out under its name, by contrasting distinctive forms and genealogies of art-science. We suggest that artscience can be understood as evidencing what we have elsewhere identified as three logics of interdisciplinarity (Barry, Born and Weszkalnys 2008), where by 'logics' we refer to different kinds of rationale, motivation or justification for interdisciplinary practices. In an earlier comparative study of interdisciplinary fields we found three logics - of accountability, innovation, and ontology - pervasive across these fields, and probed their provenance in each (ibid). By the logic of accountability we refer to a series of ways in which scientific research is increasingly required to make itself accountable to society. By the logic of innovation we draw attention to a range of arguments about the need for scientific research to fuel industrial or commercial innovation and economic growth - a reasoning that, while it has a long history, has had a particular intensity in recent decades (Barry 2001, chapter 1). However interdisciplinary research can also be motivated by the logic of ontology: an orientation in interdisciplinary practice towards effecting ontological change in both the object(s) of research, and the relations between research subjects and objects. ${ }^{2}$ As we will show, certain art-science initiatives are concerned less with making art or science accountable or innovative than with altering existing ways of thinking about the nature of art and science, as well as with transforming the relations between artists and scientists and their objects and publics. The three logics of interdisciplinarity, then, have a different prominence and distribution, and are differently entangled, in the sites of art-science that we researched. Our second aim, in indicating the ways in which art-science manifests the three logics, is to suggest that it evidences diverse modes of publicness in public knowledge. Thus, rather than intending simply to multiply the connections between science and its publics, art-science is instructive in highlighting alternative conceptions and practices of publicness.

The paper is in two parts, contrasting two radically different conceptions of art-science and their relation to publicness. In the first part we examine the logics of accountability and innovation in the guise of their association with the development of art-science in the UK, addressing debates about and interventions in the relations between science and culture from C. P. Snow's essay on the 'two cultures' to the present-day activities of the Wellcome Trust and Arts Council England. In these developments, art that is in dialogue with science is understood as a means by which the (absent) public for science can be assembled or interpellated. Here science is conceived as finished or complete, and as needing only to be communicated, understood or applied, while art provides the means through which the public is mobilised or stimulated on behalf of science. In the second part we develop an analysis of the logic of ontology in art-science. In particular, we zoom in ethnographically on a striking institutional experiment in art-science based at the University of California at Irvine: the Masters programme in Arts, Computation and Engineering (ACE). ${ }^{3}$ As we show, ACE became a crucible for working through new pedagogies and practices, as well as the institutional shape and challenges of a strong interdisciplinarity. The case of art-science at UCI is instructive, then, not because it is either unique or typical of art-science in the US, but because it indicates the possibility of a type of art-science that articulates the logic of ontology. At the same time, ACE evidences a distinctive form of publicness in relation to artscience, in which science is understood not as self-sufficient or complete, but as transformed and enhanced through its engagement with art, just as art is transformed and enhanced 
through engagement with science. Here the public conceived by art-science is not assembled or interpellated (cf Osborne and Rose 1999). Rather art-science performs the mutual transformation of both the practices and objects of science and art. In this way art-science becomes not so much a way of producing a public for science, but what we term a public experiment (cf Barry and Kimbell 2005).

\section{The Two Cultures: Art-Science in the UK}

In Britain, fifty years after its delivery, C. P. Snow's lecture on The Two Cultures (1959) still powerfully informs contemporary accounts of the relations between the arts and sciences, and the economic importance of these relations. In the lecture Snow reflected on the potential that might be released if only there were greater interaction between the arts and the sciences.

'The clashing point of two subjects, two disciplines, two cultures - of two galaxies, so far as that goes - ought to produce creative chances. In the history of mental activity that has been where some of the breakthroughs came'. But in practice, Snow continued, 'the two cultures can't talk to each other. It is bizarre how very little of twentieth-century science has been assimilated into twentieth-century art' (Snow 1959, p. 16). According to Snow, Western society was being split into 'two polar groups': on the one hand, the literary intellectuals; on the other, 'and as the most representative, the physical scientists' (Snow 1959, p. 4). In his view, if Britain was to remain a successful industrial economy, this split needed to be overcome and the value of the sciences to cultural and economic life needed to be fully recognised. The cultural divide was not just an 'English phenomenon', but it seemed 'at its sharpest in England' (ibid, p. 17). One of its consequences, Snow argued, was that arts graduates had little knowledge or understanding of science and technology, while being disproportionately represented in the executive class in government and industry: not 'one in ten [of men getting firsts in arts subjects at Cambridge] could give the loosest analysis of human organisation which [technology] needs' (ibid, p. 30). At the same time, he contended, there has been a prejudice against scientists and engineers in government and industry, and a tendency to favour Oxbridge arts graduates in appointments to the elite and the ranks of 'the great and the good' - the higher ranks of the Civil Service and the BBC, committees of public inquiry and so on. Crucially for Snow, the problem of the two cultures was inextricably linked with the demands of an economy increasingly reliant on innovation - or what Harold Wilson was to call 'the white heat of technological revolution'. Snow himself was subsequently to become a minister in the Wilson government's new Ministry of Technology (Gummett 1980, p. 45).

David Edgerton, in a recent book (2006), has argued that Snow should be understood as an influential exponent of British 'declinism', a term that Edgerton takes from Martin Wiener's text, English Culture and the Decline of the Industrial Spirit (1981). For declinists, according to Edgerton, Britain has always underinvested in science and engineering - whether in comparison with Germany (1880-90s), the USA (1950-60s and 1990s), Japan (1970s-80s), or China and India today. Snow's lecture, as is well known, elicited a stinging response from the literary critic F. R. Leavis, criticisms that Edgerton broadly endorses. Anticipating recent academic critics of New Labour, Leavis viewed Snow as a technocrat who, in his lack of understanding of culture and value, was a 'spokesman for the "technologico-Benthamite" reduction of human experience to the quantifiable' (Collini 1993, p. xxxiii).

But despite Edgerton's interest in the afterlife of Snow's 'two cultures' lecture, he has little to say about its central thesis, namely the lack of communication between the arts and sciences, nor about its continuing importance in the political imaginary of British science. In this 
political imaginary, as Snow's essay indicates, the question of the relation between the sciences and arts is not just considered an intellectual issue, but one that has critical significance for economic life. In this context one figure is notably absent from Edgerton's discussion: Raymond Williams, who came to Cambridge shortly after the Snow-Leavis exchange. Williams, in his 1958 Culture and Society, had chided Leavis for reducing the study of culture to literature and for failing in this way to acknowledge the importance of 'history, building, painting, music, philosophy, theology, political and social theory, the physical and natural sciences, anthropology and the whole body of learning' (Williams 1963/1958, p. 248, our emphasis). Where Edgerton lends support to Leavis's criticisms of Snow, Williams argued that Leavis's educational project was marked by profound ignorance and hostility towards science, technology and industry.

The significance of Williams for our analysis, and of noting his absence from Edgerton's history of this era, is not that he provides a diagnosis of British culture that we wish to endorse. Nor do we have the space to pursue the connections between the Leavis-SnowWilliams debate and the broader reconfiguration of the relations between disciplines that occurred in Britain in the 1960s (cf Agar 2008). Rather, it is that Williams is suggestive of the need for a more complex conception of the multidimensional relations between the arts, humanities and sciences, and between research and economic life, than is given in the polarised debate between Leavis and Snow. ${ }^{5}$ At the same time, for Williams, the problem was not so much the relations between the arts and sciences in general, but the disdain of both literary and scientific intellectuals for popular and vernacular forms of knowledge and cultural practice. In this way Williams's analysis prefigures the ways in which interdisciplinarity between the arts and sciences became associated in the 1990s and 2000s not only with the view that the political elite should be scientifically literate, as Snow argued, but with the growing concern to rethink the relations between scientific experts and the public. Moreover, Williams's attention to the history of cultural forms points to the importance of framing any analysis of art-science not just in terms of the history of relations between science and the public, as Nowotny et al suggest, but also in terms of art's relations with the public.

\section{Public Understanding, Public Engagement, and Innovation}

As we have seen, in his analysis of the problem of the relations between the disciplines, Snow showed little interest in the public. He was preoccupied by what he perceived to be ignorance about science among the academic and political establishment. Yet in the 1980s and 1990s, when British scientists again pointed to the existence of a cultural division between the arts and sciences, as well as to the putative deleterious economic consequences of this division, they placed great emphasis on the public as a key element in responding to these challenges. Critical to the revival of interest in the relations between the arts and sciences in Britain in the 1980s was the preparation of a report on the Public Understanding of Science by an ad hoc group of the Royal Society under the Chairmanship of the statistician and geneticist Walter Bodmer (Royal Society 1985). The report came at a time when scientists saw themselves as under attack from two directions. On the one hand, it drew attention to what was perceived to be 'anti-scientific feeling' associated with a revival of romanticism (Wolpert and Richards 1988, p. 1; cf Barry 2001 chapter 6), as well as a broad 'erosion' of public support for science (Royal Society 1985, p. 14). On the other hand, the neo-liberal economic policies of the Conservative government had resulted in substantial cuts to basic scientific research (Edgerton and Hughes 1989). But although the circumstances of its publication were entirely different, the Bodmer report replicated closely some of Snow's arguments. It proposed that 
'no pupil should study only arts, or only science, even after the age of 16' (Royal Society 1985, p. 6), and called for greater efforts on the part of scientists to 'communicate with the public'. This 'public' included not only the political and academic elites, but a series of categories including 'private individuals', 'people employed in skilled or semi-skilled occupations' and the 'middle ranks of management' (ibid, p. 7). Like Snow, the Royal Society argued that it was particularly important that the higher echelons of the Civil Service should understand science. In effect, for the Royal Society, the public was a broad aggregate, and one that was differentiated by occupation and class; and as the public understanding of science paradigm 'became something of an international movement during the 1990s', it saw as its purpose engaging 'in a kind of missionary work' that emphasised the educational and civilizing role of science (Elam and Bertilsson 2002, pp. 12-13). But the Bodmer report had a second influential theme: again echoing Snow, it argued that public education was essential in enhancing science's contribution to economic progress, indeed that economic growth depended on all fractions of the public having some understanding of science: 'there is a strong prima facie case for the existence of a link between public understanding of science and national prosperity, though the link may be as difficult to quantify as that between a company's research and development effort and its overall profitability' (Royal Society 1985, p. 9).

By the mid 1990s, in the wake of the Bodmer report, it appeared that the wisdom of Snow's thesis was finally being recognised in the UK and was leading to practical proposals as a spate of initiatives occurred aimed at supporting the rapidly emerging interdisciplinary field of 'science-art'. ${ }^{6}$ In 1996 the Wellcome Trust, one of the foremost funders of British medical research, launched the first of a series of funding programmes for art-science projects. The Trust's programme was explicitly intended to bridge the two cultures by enlisting artists to foster the public's relationship with science. An administrator explained, 'There's a public out there, some of whom are suspicious, some aren't interested; some of them run a thousand miles in the opposite direction when you tell them about science....[but a] contemporary art show which happens to be about science reaches people who wouldn't ordinarily do it and you get them thinking about science' ${ }^{7}$ The Wellcome Trust's programmes were followed in 1999 by the formation of the Sciart Consortium, in which the Trust was joined by Arts Council England, the National Endowment for Science, Technology and the Arts, the Calouste Gulbenkian Foundation, the Scottish Arts Council and the British Council (Webster 2006, p. 76). While in 2003, Arts Council England and the Arts and Humanities Research Board initiated the Arts and Science Research Fellowship programme to fund collaborative projects between artists and scientists.

Despite differences between these initiatives, they broadly follow Snow and the Royal Society in drawing connections between the lack of communication between the arts and sciences and the challenge of responding to the economic demands of a technological society. They articulate, that is to say, the logic of innovation. In the words of an Arts Council England executive, the ACE/AHRB Fellowship scheme arose from the 'conjunction of interests of both organisations' and 'would be an ideal ground for...connecting art and science and [privileging] openness and knowledge sharing across disciplines'; at the same time it met the wider public interest 'in using public funding to support research and development in the interests of "new knowledge" and innovation' (Ferran 2006, p. 443). Indeed the ACE/AHRB scheme cited as formative in its design and legitimation the influence both of the EU Lisbon Agenda of 2000, with its knowledge economy focus, and of a 2001 report by the UK Council on Science and Technology which 'declared that the divisions in 
education and research between the arts, humanities and science were anachronistic and detrimental to the future of Britain's economy' (ibid).

But in addition to the rationale of fostering innovation, certain art-science funding initiatives from the mid 1990s articulate the logic of accountability, evident in their increasing orientation towards the movement that succeeded the public understanding of science: what was called 'public engagement'. In the words of the Wellcome Trust:

We believe the arts are an effective way of stimulating debate and engaging people with biomedical science. Visual art, music, moving image, creative writing and performance can reach new audiences which may not traditionally be interested in science and provide new ways of thinking about the social, cultural and ethical issues around contemporary science. Collaborative and interdisciplinary practice across the arts and sciences can help to provide new perspectives on both fields. The arts can also provide imaginative ways of engaging and educating young people in the field of science. (Wellcome Trust 2009)

In this account, through the mediation of art-science, the public are not merely enjoined to understand science, but given 'new ways of thinking about...social, cultural and ethical issues'. Art-science is therefore seen as assisting in the formation of an interested and engaged public, one that will be disposed, and sufficiently informed, to take part in rational debate about issues raised by scientific developments (cf Davies 2006). The justification of funding for art-science therefore reflected, and played a key part in, a broader shift from the mid 1990s towards public engagement as opposed to public understanding as the preferred mode of interaction between science and its publics, envisaging a new kind of active, deliberative scientific citizenship (Elam and Bertilsson 2003, Irwin and Michael 2003, Turney 2006; cf Callon and Rabeharisoa 2004).).

In part, the shift to public engagement represented a response by the funding agencies to a critique by social scientists - one that echoes Williams's earlier critique of Leavis's culturalism - of the assumption implicit in the idea of public understanding of science that the public was conceived in terms of a lack, a conception that failed to recognise the existence of 'alternative, more culturally rooted and legitimate forms of collective public knowledge' (Wynne 1996, p. 46, Turney 1998). But the public engagement discourse responded also to a sense of declining trust in scientific institutions associated with growing public anxiety over environmental and health risks (Poortinga and Pidgeon 2005). Thus in 2000, in the aftermath of the BSE debacle, the House of Lords select committee declared that there was a 'crisis' in the relations between science and society: ${ }^{8}$

$[\mathrm{P}]$ ublic confidence in scientific advice to Government has been rocked by a series of events, culminating in the BSE fiasco; and many people are deeply uneasy about the huge opportunities presented by areas of science including biotechnology and information technology, which seem to be advancing far ahead of their awareness and assent. In turn, public unease, mistrust and occasional outright hostility are breeding a climate of deep anxiety among scientists themselves (House of Lords 2000, 1.1, our emphasis)

In this political situation there was a conviction among the funding bodies that art-science, along with other practices of public engagement, would make it possible to manage the ways in which the public might develop not only cognitive, but interactive and affective involvements with science. In this view, in place of a mistrustful, disengaged and anxious 
population, art-science would assist by assembling a public that was not only ready to participate in debate about the risks raised by scientific research, but excited and entranced by science. At best, art-science might align the public's hopes and passions more precisely with the hopes and passions of research institutions: art-science could become a device for the governance of affect (cf Anderson 2007, Thrift 2008).

Art-science is conceived, then, as rendering science more accountable and communicable to the public, whether through its capacity to attract the public to science through its aestheticisation, or by bringing affective and expressive experience into the domain of science. In this sense, art-science offers to assemble a public for science in a form to which science can then consider itself accountable; science is rendered accountable to a public that is, in turn, properly disposed towards it. There are three points to note. First, the type of public envisaged here is one that, in Michael Warner's Althusserian formulation, 'exists by virtue of being addressed' (Warner 2005, p. 67). Scientific research is taken as a given, and art provides a means through which the public can be aggregated and then engaged in relation to it. Second, the role of art-science in assembling this public is explicitly an instrumental one. Such an instrumental conception was acknowledged by administrators: '[Art-science has] always been sold [to funding body executives] around a very pragmatic and instrumentalist notion of what's going on... [and] I've actually come back to a position of "what's wrong with instrumentalism?". . Indeed it was a critique of instrumental notions of art-science that generated some of the funding schemes from the later 1990s in which, as an alternative justification, innovation came to the fore. But - and a final point - whether motivated by accountability or innovation, in the trajectories of UK art-science that we have sketched, interdisciplinarity is uniformly conceived in the terms of what we have called the service-subordination mode - auguring hierarchical relations in which art is enrolled in the service of science (Barry, Born and Weszkalnys 2008, pp. 28-9).

\section{Art-Science and Conceptual Art: ACE is the space ${ }^{10}$}

It is striking that in accounts given by UK funding bodies, art-science is not portrayed as a field that has any substantial existence in itself - unlike, say, biochemistry or nanotechnology. In effect, the rationale for support for art-science is given not by its relation to art but to science, extending further the capacities of research institutions to assemble a public that will be engaged, or to contribute to the development of a knowledge economy. In contrast, an influential Rockefeller-funded research report on art-science in 1999 sought to give an alternative account of art-science (Century 1999). This was achieved by construing the prehistory of art-science in terms of the evolution of a particular social form, the 'studio lab', seen as a privileged site of hybrid, innovative practices, "where new media technologies are...developed in co-evolution with their creative application' (ibid, p. 2). The Rockefeller report therefore aimed to legitimise the field, and specifically the studio lab (examples mentioned include Bell Labs, MIT's Media Laboratory, Xerox PARC, IRCAM and ZKM) as a valuable incubus for innovation in the knowledge economy - as an institutional form worth investing in. However, like the British funding agencies, the Rockefeller report again presents a restricted account of the field, one that domesticates the ramifying and sometimes controversial links between art, science and technology across the $20^{\text {th }}$ century. Thus, in the funding institutions' concern with the service that art can perform for innovation or scientific accountability, the conception that artists and art theorists themselves have of art-science, the assessments that they make of its potential and value, and the genealogies of art-science as a category of specifically art-historical practice, all tend to be backgrounded or obscured (cf Boltanski and Thévenot 2006). 
A clear difficulty facing any analysis of art-science, then, stems from the difference between the way that the category has been deployed by the funding agencies and its existence as a category for artists. Indeed, amongst the practitioners that we interviewed, art-science and its cognates are portrayed as stemming from a much larger, heterogeneous - if contested - space of historical coordinates. They are experienced as having their genesis in the mutual disturbances or interferences thrown up at the intersection of three distinct but related genealogies. The first is conceptual and post-conceptual art, including performance, activist and installation art; the second encompasses historical art and technology movements, as they issue in the multi-, inter- and trans-media arts of the present; and the third comprises, broadly, developments and debates around the computational and bio sciences and technologies. In relation to art these coordinates are traced, depending on the individual artist, through classic origins in the work of Muybridge and Duchamp, founding father of conceptualism, via such mid $20^{\text {th }}$ century figures and groups as John Cage, Jean Tinguely, Billy Klüver and Experiments in Art and Technology, Nam June Paik, Jack Burnham, Jim Pomeroy, Hans Haacke, Fluxus, Art and Language, and the Artist Placement Group, to contemporary artists including Laurie Anderson, Perry Hoberman, Natalie Jeremijenko, Geert Lovink, Stelarc, Eduardo Kac, Oron Catts, and groups such as Adbusters, RTMark, Critical Art Ensemble, Survival Research Labs, the Red Group at Xerox PARC, and SymbioticA (Wilson 2002, Osborne 2002, Corris 2004, Weszkalnys 2005, Buchman 2006). Clearly these coordinates portray a series of decidedly artistic trajectories - trajectories, however, that intersect with technological and scientific experimentation and controversy. The various genealogies given by practitioners of art-science, then, are not definitive. Rather, they generate together a type of perspectivism, one that etches out a diachronic space of practices and potentials. What is at stake is artists' varying constructions of the lineages and networks of retentions and protentions - that is, of practices and events that matter and that are considered generative within which they situate their current practices (Born 2005, 2008, Gell 1998; cf Fraser 2006).

Having indicated the plural genealogies of art-science, in what follows we do not attempt definitively to map the multiplicity of the field. Instead we focus on a particular example: an institutional experiment in art-science based at the University of California at Irvine, in the guise of the Masters programme in Arts, Computation and Engineering (ACE). While this example cannot be taken as typical of art-science in general, it nonetheless makes clear what we argue are critical features of the work of some practitioners; that is, an orientation towards what we have termed the logic of ontology, and in some instances a concern with the production of what we will call public experiments. In the UK, a similar orientation is evident in the work of artists associated with the small Arts Catalyst organisation which, in the 1990s, was one of the pioneers of art-science in the UK. ${ }^{11}$

If we attend to the intellectual contents of the ACE teaching programme, a complex space of genealogies of art-science comes into view. In outlining these genealogies, we draw on the substance of and teaching materials provided for a core seminar of the ACE programme taught by artist-engineer Simon Penny, the founding Director of ACE. ${ }^{12}$ One trajectory begins with the critique of Artificial Intelligence via phenomenological notions of embodiment and situatedness (Dreyfus, Agre); through the 'bottom-up', biologically-based simulation of embodiment and situatedness in intelligent robotics (Brooks); through automatic design and evolvable robotic lifeforms (Lipson and Pollack); through artificial life (ALife) using biological concepts as a basis for computation via 'self-reproducing cellular automata' (Langton); through the problem of emergence - that is, designing 'open-state' 
artificial organisms capable of creative and learning behaviour (Cariani); through artificial cultures - the design of 'dynamically-evolving mobile autonomous agents that serve to embody hypotheses for understanding cultural behaviour' (Gessler); through computational modelling of a grammar to describe the morphology and nervous systems of virtual creatures, so as to achieve 'dynamic systems with emergent complexity' in the guise of autonomous behaviour, as well as their evolution via 'mating' and 'competition' (Sims); through the design of interactive systems with rudimentary agency as artworks, generating an 'aesthetics of behaviour' (Penny); ${ }^{13}$ through computer-based generative art, with reference to cybernetics and ALife, which envisages creative behaviour in artificial systems and gestures to the 'computational sublime' (McCormack and Dorin); to interactive artworks that use 'expressive AI' to generate avatars with emotion (Mateas). Meanwhile the phenomenological critique of AI (which draws on Husserl, Heidegger and Schutz) takes another route through the field of Human Computer Interaction and its 'embodied interaction' paradigm, manifest in the tangible, ubiquitous and social computing advocated by Paul Dourish (Dourish 2001) an ACE faculty member and iconic UCI interdisciplinary figure based in Informatics, with affiliations not only to ACE but to a host of other UCI interdisciplinary initiatives, including CalIT $^{2}$ and the Center for Ethnography. ${ }^{14}$

At ACE this trajectory runs in parallel with another, starting from the 'non-modern' epistemology and ontology of the early British cyberneticists Beer and Pask and their work on biological computing, self-organisation and dynamic equilibrium (Pickering 2002, 2005). Beer and Pask offer a vision of symmetrical, non-hierarchical relations (or assemblages) between entities - nature and culture, human and non-human, ponds and electrolytic cells mobilised by their performative qualities into adaptive systems, themselves liable to openended transformation in dialogue with environmental conditions. The trope of selforganisation migrates into the biology of cognition and the idea of autopoiesis (Maturana and Varela), from where it folds back to meet the challenge for robotics of simulating autonomy, sentience and environmental responsiveness in artificial organisms.

A third ACE trajectory, finally, cuts through and destabilises this universe via feminist and critical cultural studies of science and technology (Fox Keller, Haraway, Martin, Kember), throwing into relief the ideological underpinnings of, for instance, the alliance between the new biology and ALife, and charting the collusive materialisation and re-engineering of the new sciences in the guise of 'posthuman', ALife technological systems.

What does this space of overlapping genealogies portend? First, it is essential to note the importance of these multiple histories of art-science to practitioners, which are radically different from the kinds of rationales that - as we have seen - animate the actions of the funding bodies. Second, we want to draw out the variance between these ACE genealogies and the rationales of the funding bodies along two axes: on the one hand, the presence or absence in them of an engagement with the politicised elements of conceptual art, as well as of critical and feminist science and technology studies; on the other hand, and following on, the degree to which they entertain or not the basic premise of conceptual art: its commitment to an entirely distinctive ontology of art. Originating in responses in the 1960 s to the impasses of formalist modernism, conceptual art has itself been a heterogeneous movement entailing a questioning of art as object, as site, and as social relations, each of which has been targeted for transformation by particular conceptual lineages. Conceptualism, then, can be sketched through a series of negations: negation of material objectivity and the primacy of visual form - in favour of the temporality of intermedia and multimedia performances and events; negation of art's deterritorialised commodity form - in favour of installations and 
site-specific works that insist on the value of place; and negation of the philosophy of art's autonomy, and this in several ways - in favour of works that address the politics of everyday life through interventions in existing media and publicity; works allied to wider political and ideological conflicts; works that probe the politics of art as an institution; and works that foreground art's social relations and embeddedness, reconceiving art as various kinds of social practice and research (Osborne 2002, pp. 18-19, Newman 2002, Corris 2004). Running through the rock of conceptual art, then, is a constitutive tension between orientations that are primarily formal and to do with medium and materials, and those that are primarily concerned with the production of political, social and cultural experiments. To return, then, to the variance: while the ACE genealogies encompass both critical science studies and conceptualism's reworking of art's ontology, the funding institutions' cleaving to accountability and innovation tends to obscure if not occlude these potentials.

\section{A Public Experiment: PigeonBlog}

What do we mean by a public experiment? And what is the relation between a public experiment and the types of experimentation found in scientific research? The work of the artist and ACE faculty member Beatriz Da Costa can exemplify an orientation towards the production of public experiments, in a way that cuts across distinctions between scientific and artistic experimentation and that manifests a particular conception of publicness. At ACE, Da Costa's work entails close collaboration with scientists; two of her UCI collaborators, from systems biology and environmental health science, had experienced successful multidisciplinary scientific projects and were predisposed to think positively about interdisciplinary work. Da Costa described herself as omnivorous: her technique was to get extremely close to current scientific problematics through several years of immersion in the work of scientific colleagues - a process appreciated by her collaborators. The resulting projects promised to generate not only artistic interest but scientific gains. Indeed they were intended to be trebly inventive - creating scientific, artistic and political value. Her project PigeonBlog (2006) was a public art event, a 'social experiment between human and nonhuman animals', which centred on the provision for ordinary people of low-tech means of collecting data on air pollution in their locality.

In PigeonBlog homing pigeons were released equipped with GPS-enabled electronic sensors which, as they flew over urban areas, sent back real-time location-based pollution data and imaging to an online mapping and blogging site. The information was analysed and modelled on the website, where it sat next to educational material. The aim was to encourage participation and increase awareness about pollution exposure. In Da Costa's words, 'by using homing pigeons as the "reporters" of current air pollution levels we are hoping to achieve two main goals: 1) to re-invoke urgency around a topic that has serious health consequences, but lacks public action and commitment to change; and 2) to broaden the notion of grassroots scientific data gathering while building bridges between scientific research agendas and activist-oriented citizen concerns'. ${ }^{15}$

But the project also answered a gap in the science and technology of air pollution monitoring. Typically, air pollution monitoring in major cities depends on an array of fixed monitoring stations. In Los Angeles, for example, 37 monitoring stations serve 17 million people. However readings from these stations, since they are derived only from specific points, provide a very limited basis for estimating the state of the air mass over extremely large areas. In PigeonBlog the limitations of this approach to the construction of a metrological regime (Barry 2002) are considered, in part, political. As Da Costa's scientist collaborator, 
Rufus Edwards, explained: 'People living in poor neighbourhoods where more pollution sources are located will individually have greater exposure than the air monitoring station would have you believe; so they are less protected by our regulations. Whereas, the affluent people who live here [in Orange County] on hillsides have cleaner air than the monitoring site suggests. When you have these systematic differences in exposure, you have the potential for environmental injustice, with certain segments of the population receiving a greater pollution burden. If you look at this worldwide, the populations that receive more of the air pollution are the poor'. ${ }^{16} \mathrm{He}$ continued that for PigeonBlog, Da Costa had herself researched and developed a cheap, portable monitor, and he had also developed one: 'It became clear that we could combine our monitors and make what would be a new and interesting monitor that measures multiple pollutants together. So in addition to her art demonstration, there are other applications for such a monitor in improving the way we do health research. Releasing the pigeons, depending on their flight paths, tells us a lot about how pollution is dispersing spatially over the city, which we had no way of calibrating before. To get an idea of how air pollutants are dispersing, you need simultaneous measurements in multiple areas. Using pigeons is a very good way, because all of a sudden you have mobile monitors that can fly on specified flight paths, and by tracking the pigeons you have minute by minute GPS monitoring of the pollution plume over the city. You trade acuity for ease of measurement, but these are empowering technologies.... Once we develop these tools, there are other applications. What a pigeon can carry is ideally suited in size and weight for one person to carry, so we can start to get individual information that will allow us to look at our epidemiology and health research in a new way; in fact I'd like to do a full-scale epidemiological study using these sensors. Where it's also very powerful is that it can measure continuously for an extended period of time, so on an individual level you start to get longitudinal measurements.' 17

Three observations follow from Da Costa and Edwards's project. The first is that PidgeonBlog points towards a reconceptualisation of air quality as an object of measurement. As we have noted, air quality is measured at a number of fixed points in most major cities, as was the case in Los Angeles. However, such an approach is problematic on two grounds, as the project makes apparent. On the one hand, it fails to describe the ways in which air pollution moves and disperses in time and space. Through the use of pigeons and potentially humans as carriers of monitoring devices, Da Costa and Edwards's project pointed towards the possibility of mapping the dynamic geography of air quality. On the other hand, existing air quality monitoring regimes fail to address the question of how individuals interact with air, by breathing particular mixtures and quantities of pollutants during the course of their everyday activity in the city (Barry 2001). In making measurement mobile, Da Costa and Edwards's approach points to a recognition that air quality should not be considered a property of air in itself, but should be understood as a relation between air and those who breathe and are affected by it, who are in turn differentiated by class and location. In this way, Da Costa and Edwards's work does not simply offer a service to science as it is; it makes a scientific contribution by pointing out the need to reconceptualise what the object of air quality research is. It enacts a logic of ontology: reconfiguring air quality not as a property of air itself, but as a relation between pollution and those who are affected by it. In this context, art-science projects like PigeonBlog do something more than present ready-made science to the public. Rather, they contribute to the generation of something new within scientific practice itself, challenging the boundaries of disciplinary authority (cf Stengers 1997, p. 18). 
A second observation is that Da Costa and Edwards's project points to a distinction between the provision of public information and the practice of a public experiment. Air quality monitoring data are typically presented in public as finished or inert information. This information reports the results of a standardised type of metrological practice, governed by national or international standards, and based on a science of air pollution that is wellestablished. The data are presented as public information in order that the public itself interpellated by the data - can become informed (Barry 2001, p. 153). In contrast, the informational outputs of PigeonBlog are less substantial and systematic, and the practice of measurement takes an experimental and local form. The aim of the project is not to provide public information while hailing the formation of an abstract public. Instead it is to develop a different kind of public knowledge of air quality: one that highlights the critical significance of its social-geographical variation, and that invites those most affected by this variation to participate in the practices of knowledge production. This is a type of public knowledge, then, that is in principle unfinished, in-process and dialogical, developing through the reflexive relations between participants, who are both the subjects and objects of knowledge, a knowledge that enfolds both themselves and their relations with their local environment.

A third observation is that PigeonBlog transforms and multiplies art such that it encompasses enduring processes of scientific and social research, public performance event, website and scientific papers, and social relations between artist-scientist and affected local population, who become participants in the work. Dada-esque and deadly serious, PigeonBlog traverses the boundaries that would contain it. In an original design for PigeonBlog, it was intended that the pigeons conducting air quality monitoring would be accompanied by 'embedded reporter' pigeons, which would carry cameras, thereby providing a visual record of the localities. The idea for PigeonBlog derived in part from the work of Julius Neubronner, a German engineer who in 1903 patented the idea of a pigeon-born camera as a reconnaissance device. Likewise, PigeonBlog was intended visually to record the devastated and polluted terrain of Los Angeles county, one of 'the most polluted areas' of the USA, and one in which the "economic concerns of the automotive industry tend to motivate policy decisions far more than human health'. ${ }^{18}$ A war zone of a kind, which only pigeons would be able to map. Thus, as we have stressed, while PigeonBlog was an interdisciplinary experiment in art-science, it should be understood in relation to the broader history of the multiple lineages of conceptual and post-conceptual art. This is because it gathers within itself and unleashes the cumulative, protentive power and imagination of forty years of conceptualism, as relayed through a decade of contemporary art-science. It augurs art as a new kind of experience by reference to and retention of this rich prehistory (Born 2009, Gell 1998), both concretizing and extending conceptualism's protean ontological ambitions. At the same time, rather than take a subordinate role in the communication of a finished science, here art draws upon but also augments the resources of science. PigeonBlog makes a scientific contribution, while reconfiguring the objects both of art and of scientific research.

\section{Conclusions: Art-Science, the Public, and their Relation}

For some commentators on art-science, projects like Da Costa's risk an excessive moralism (Zylinska 2009, p. 208); ${ }^{19}$ they might be accused of taking on a political-educational function that is not so distant from the educational mission envisaged by the proponents of public understanding of science. But we want finally to draw out a critical distinction that disturbs that equation. Our case is that PigeonBlog was not addressed to a pre-formed public (Bell 2007), one that would come into existence through its interpellation by a pre-formed scientific knowledge. Rather, PigeonBlog amounted to an experiment through which public, 
knowledge, and their relation were expected to emerge in a different form. One way to grasp this difference would be to hold Warner's Althusserian formulation of the public interpellated through practices of cultural production, which privileges a textual model, up against an Arendt-ian, anti-teleological conception of the public, which takes as its model the public performance event (cf Barry and Kimbell 2005). If Arendt's concern was with the systematic renewal of political praxis and the public realm, her preferred idiom for political action was the performing arts. For Arendt, plurality was the fundamental condition for such action, the essence of which was continuous, direct civic participation. As Dana Villa suggests, Arendt's performance model "emphasises the embeddedness of action in the "already existing web of human relationships" while stressing its phenomenality, its need for an audience.... [She] directly links the meaning-creative capacity of initiatory action to its "futility, boundlessness, and uncertainty of outcome", where 'boundless' implies the creation of 'myriad new relationships [and] unforeseen constellations' ${ }^{20}$ Moreover Arendt insists that the public realm constituted through political action or performance has a 'unique revelatory capacity' by virtue of being both artificial and autonomous (Villa 1996, pp. 84-5). The public experiment that is PigeonBlog recalls such a conception of an agonistic, performance-engendered, participatory public - a performance that is artificial, oriented to political action, and the outcome of which is uncertain.

We can pursue this difference through Barbara Cassin's productive discussion, drawing in part on Arendt, of the contrasting Greek rhetorical forms, apodeixis and epideixis. Cassin begins with a paradox: 'Truth is sometimes defeated. When it happens, it's man's fault, a human wrong against nature.... This is precisely why men (sic) need rhetoric: we need rhetoric to help truth...against rhetoric' (Cassin 2005, pp. 858-60). Apodeixis refers to a kind of 'proof-demonstration', 'the art of showing "from" (apo) that which is shown', a faithful showing from the (finished) knowledge or truth. Cassin continues that epideixis, in contrast, "is the art of "showing" (deiknumi) "in front" (epi), in the presence of a public, to make a show. Epideixis: you speak to, audience-oriented; apodeixis: you speak of, object-oriented' (ibid, p. 862). But the difference extends also to the performative qualities of the two rhetorical modes. Where apodeixis follows the object by confirming 'what is or seems to be, epideixis makes it be' (ibid, our emphasis). Epideixis is therefore the most rhetorical or artful of rhetorical genres. Crucially, for Cassin, epideixis is 'an active maker' of the world: it can be understood as a rhetorical demonstration that is intended to move (in both senses) its interlocutors towards both new objects and new common values (koina) - new matters of concern (Latour and Weibel 2005, Fraser 2006) - a shift from 'consensus...to invention, from liturgy to happening' (ibid, p. 863, emphasis in the original). Epideixis, that is to say, encapsulates the transformative power of speech and art, a power to move that can reconfigure not only what kind of knowledge is held in common but, simultaneously, the publics that coalesce around and the social relations that are referenced by that knowledge.

By now, in outlining Cassin's argument, our rhetorical intention should be plain. It is to create a kind of proof-effect or equation in which [apodeixis : epideixis] stands for [public understanding : public experiment]. As a form of epideixis, public experiments do not so much present existing scientific knowledge to the public, as forge relations between new knowledge, things, locations and persons that did not exist before - in this way producing truth, public, and their relation at the same time. Cassin herself draws a distinction between the presentation of what she terms 'pre-existing proofs' and managing evidence: "'managing evidence" does not mean...dealing with pre-existent proofs but contriving new types of obviousness' (Cassin 2005, p. 864). It should be obvious, after PigeonBlog, that air quality is not just a property of urban air, but a matter of social knowledge and social justice. While 
PigeonBlog cannot be seen as typical of art-science, it demonstrates the difference between a project of public understanding and a project of public experiment - and between the logics of accountability and innovation, and the logic of ontology. In doing so, rather than conceive of art-science as a manifestation of a broader transformation in the mode of production of knowledge, PigeonBlog insists on the need to attend to the specificity, heterogeneity and complex genealogies of art-science. 


\section{References}

Agar, J. (2008) 'What happened in the sixties', British Journal for the History of Science, vol. 41, no. 4, pp. 567-600

Anderson, B. (2007) 'Hope for nanotechnology: Anticipatory knowledge and governance of affect', Area, vol. 19, pp. 156-165

Arendt, H. (1989/1958) The Human Condition, University of Chicago Press, Chicago

Barry, A. (2001) Political Machines: Governing a Technological Society, Athlone, London

Barry, A. (2002) 'The Anti-Political Economy', Economy and Society, vol. 31, no. 2, pp. $268-84$

Barry, A., G. Born and G. Weszkalnys (2008) 'Logics of Interdisciplinarity', Economy and Society, vol. 37, no. 1, pp. 20-49

Barry, A and L. Kimbell (2005) 'Pindices' in B Latour and P Weibel (eds) Making Things Public, Cambridge, MA: MIT

Bell, V (2007) Culture and Performance: The Challenge of Ethics, Politics and Feminist Theory, Berg, Oxford

Bodmer, W (1986) 'The public understanding of science', Bernal Lecture, Birkbeck College

Boltanski, L and L Thévenot (2006) On Justification: Economies of Worth, Princeton University Press, Princeton

Born, G (1995) Rationalising Culture: IRCAM, Boulez and the Institutionalisation of the Musical Avant-Garde, Berkeley, CA: California University Press

Born, G (2005) 'On musical mediation: ontology, technology and creativity', Twentieth Century Music, vol. 2, no. 1, pp. 7-36

Born, G (2008) 'The social and the aesthetic: methodological principles in the study of cultural production' in J. Alexander and I Reed (eds) Meaning and Method: the cultural approach to sociology, Boulder, CO: Paradigm Press

Buchman, S. (2006), 'From systems-oriented art to biopolitical art practice' in M. Vishmidt (ed), Media Mutandis: a NODE.London Reader, London: Node.London.

Callon, M. and V. Rabeharisoa (2004) 'Gino's Lesson on Humanity: Genetics, Mutual Entanglements and the Sociologists' Role', Economy and Society, vol. 33, pp. 1-27

Cassin, B (2005) 'Managing Evidence' in Latour and Weibel (eds), pp. 858-865

Century, M (1999) Pathways to Innovation in Digital Culture. Report for the Rockefeller Foundation 
Collini, S (1993) 'Introduction' to CP Snow The Two Cultures, Cambridge: Cambridge University Press

Corris, M (ed.) (2004) Conceptual Art: Theory, Myth and Practice, Cambridge: Cambridge University Press

Davies, G (2006) 'Mapping deliberation: calculation, articulation and intervention in the politics of organ transplantation', Economy and Society, vol. 35, no. 2, pp. 232-58

Dourish, P (2001) Where the Action Is: The Foundations of Embodied Interaction, MIT press, Cambridge, MA

Eagleton, T (1988) 'Resources for a journey of hope: the significance of Raymond Williams', New Left Review, 168, pp. 3-11

Edgerton, D (2006) Warfare State: Britain 1920-1970, Cambridge University Press, Cambridge

Edgerton D and K Hughes (1989) 'The Poverty of Science: a critical analysis of scientific and industrial policy under Mrs Thatcher', Public Administration, vol. 67, no. 4, pp. 419-433

Elam, M. and M. Bertilsson (2003) 'Consuming, Engaging and Confronting Science: the Emerging Dimensions of Scientific Citizenship', European Journal of Social Theory, vol. 6, pp. 233-251

Ferran, B (2006) 'Creating a Program of Support for Art and Science Collaborations', Leonardo, vol.39, no. 5, pp. 442-446

Fraser, M (2006) 'The ethics of reality and virtual reality: Latour, facts and values', History of the Human Sciences, vol. 5, no. 19, pp. 45-72

Gell, A (1998) Art and Agency, Oxford University Press, Oxford.

Gummett, P (1980) Scientists in Whitehall, Manchester University Press, Manchester.

House of Lords (2000) Science and Society, Third report of the House of Lords select committee on Science and Technology session 1999-2000, HL38

Irwin, A and M Michael (2003) Science, Social Theory and Public Knowledge, Open University Press, Maidenhead

Knight, D (2006) Public Understanding of Science: a history of communicating scientific ideas, Routledge, London

Latour, B and P Weibel (eds) (2005) Making Things Public: Atmospheres of Democracy, MIT press, Cambridge, MA

Marres, N (2005) No Issue, No Public: Democratic Deficits and the Displacement of Politics, $\mathrm{PhD}$ thesis, University of Amsterdam 
Osborne, P (ed.) (2002) Conceptual Art, London: Phaidon

Osborne, T and N Rose (1999) 'Do the social sciences create phenomena? The example of public opinion research', British Journal of Sociology, vol. 50, no. 3, pp. 367-396

Pickering A (2002) 'Cybernetics and the mangle: Ashby, Beer and Pask,' Social Studies of Science, vol. 32, pp. 413-37

Pickering, A (2005) 'Beyond design: Cybernetics, biological computers and hylozoism', paper presented to the International Conference on the Philosophy of Technology, Copenhagen, October. (Reprinted in ACE teaching materials).

Poortinga, W. and Pidgeon, N.F. (2005) Trust in risk regulation: cause or consequence of the acceptability of GM food? Risk Analysis, vol. 25, pp. 199-209.

Royal Society (2006) Report of the ad hoc committee on the Public Understanding of Science, London, http://royalsociety.org/displaypagedoc.asp?id=26406

Snow, CP (1959) The Two Cultures, Cambridge University Press, Cambridge

Stengers, I (1997) Power and Invention, Minnesota University Press, Minneapolis

Thrift, N (2008) Non-Representational Theory, Routledge, London

Turney, J (1998) To know science is to love it? Observations from public understanding of science research, COPUS/Royal Society, London

Turney, J (ed) (2006) Engaging Science: Thoughts, Deeds, Analysis, and Action, Wellcome Trust, London

Villa, D (1996) Arendt and Heidegger: the fate of the Political, Princeton University Press, Princeton

Webster, S (ed) (2006) 'Art, Science and the Public', in Turney (ed.)

Weszkalnys, G (2005) Science/art: a preliminary report, Goldsmiths College Centre for the Study of Invention and Social Process, unpublished research report

Weszkalnys, G (2006) ‘Mapping interdisciplinarity', research report, School of Geography and the Environment, Oxford University

http://www.geog.ox.ac.uk/research/technologies/projects/mapping-interdisciplinarity.pdf

Warner, M (2005) Publics and Counterpublics, Zone, New York

Williams, R (1963/1958) Culture and Society 1780-1950, Chatto and Windus, London

Wynne, B (1996) 'May the sheep safely graze? A reflexive view of the expert-lay knowledge divide', in S Lash, B Szersynski and B Wynne (eds) Risk, Environment and Modernity:

Towards a New Ecology, Sage, London 


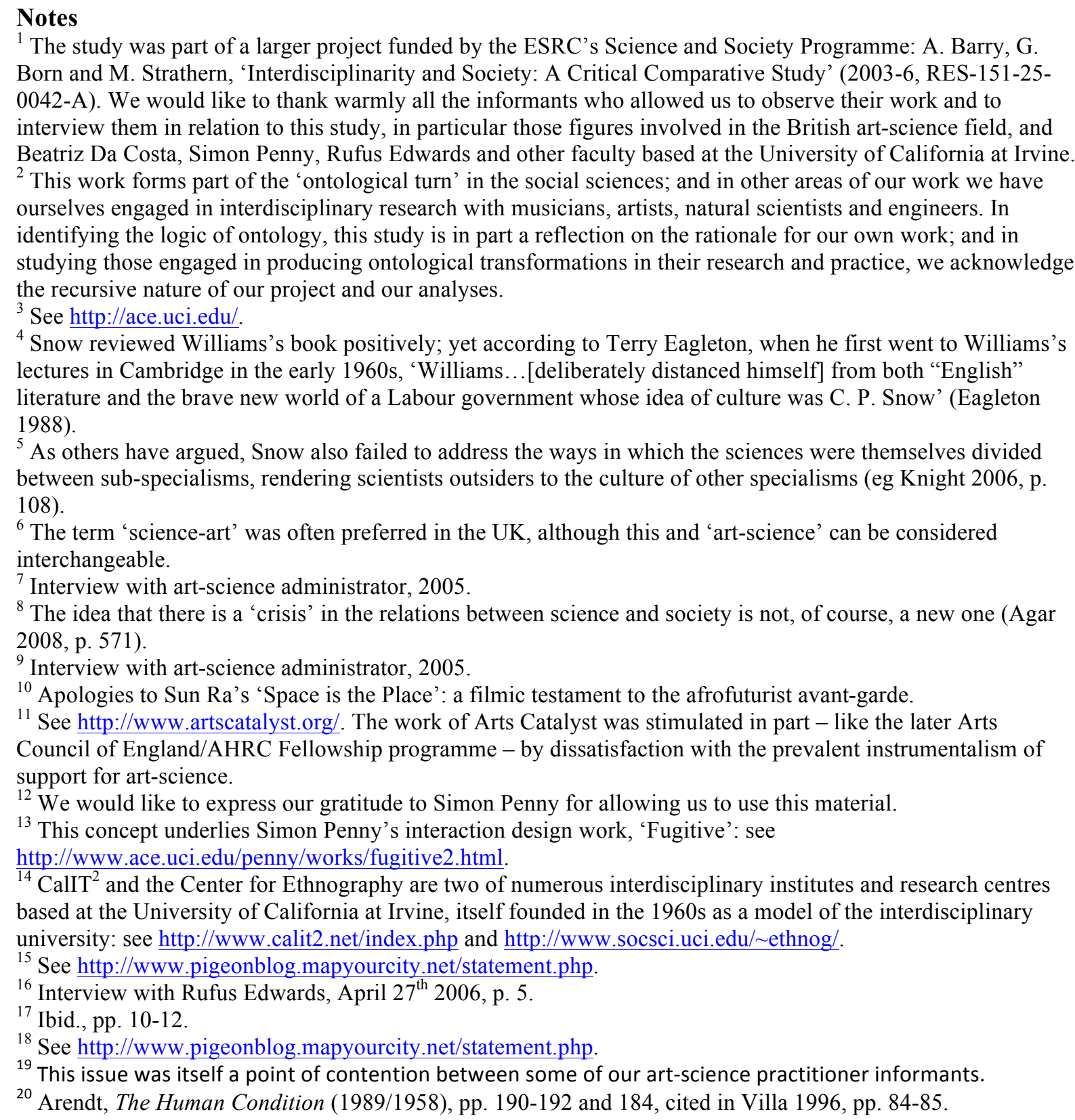

